\title{
Endothelium in control
}

A $\mathrm{H}$ Henderson

Clinical science has evolved since the days of Sir Thomas Lewis, who gave the St Cyres lecture in 1931 and whose eponymous chair I occupy. It involves still the penetration of astute clinical observation, but has come increasingly to embrace the elucidation of underlying mechanisms in the more controlled conditions of the laboratory. Its compass is being stretched by the reductionism of molecular and cell biology, but these exciting developments do not exonerate us from the ever daunting task of seeking to understand the coordinated behaviour of the whole. Perhaps biomathematics will give new impetus to our efforts to discern form in the noise. Never was there greater need for cross-talk between the different scientific disciplines and between scientists and clinicians.

The greatest growth area in cardiovascular science over recent years must surely be in the role of endothelium. Not only is there a lot of it-equivalent in mass to five normal hearts and in area to half a dozen tennis courts per standard $70 \mathrm{~kg}$ man-but it is coming to be recognised as a cardiovascular endocrine organ in its own right, occupying a critically strategic interface between blood and body, and subserving a multitude of regulatory roles. These range from acting as a selective permeability barrier, through vasomotor control, pro- and antithrombotic mechanisms and regulation of vascular growth, to metabolic and immunological activity. We here consider just one-namely the production of endothelium derived relaxing factor (EDRF), a powerful vasodilator substance released from the endothelium of all blood vessels of all species studied.

\section{Endothelium derived relaxing factor THE PHENOMENON DISCOVERED}

Before 1980, the existence of EDRF was unknown. It was in 1980 that Furchgott and Zawadski published their now classic paper describing endothelium dependent vasodilatation to acetylcholine. ${ }^{1}$ They had elucidated the paradox, long known to pharmacologists, that acetylcholine was vasodilator in vivo yet vasoconstrictor when studied in vitro with arterial strip preparations (where it transpired that the delicate endothelium is generally inadvertently removed during preparation). This explained the findings of our own studies at that time, for we had serendipitously (and initially unknowingly) encountered the phenomenon while developing an isolated perfused coronary artery preparation of the rabbit to study vasomotor regulatory mechanisms. As we gained experience with the preparation, frustratingly we met with increasing difficulty in getting the arteries to constrict. ${ }^{2}$ Indeed constrictor responses to the usual vasoconstrictor agents were virtually abolished with better preparation due, it became apparent, to endothelial preservation.

Furchgott had suggested that the endothelium dependent vasodilator influence might be a humoral factor. ${ }^{1}$ We developed a cascade bioassay system in which effluent from a perfused endothelialised "donor" artery perfused a denuded, pre-constricted "recipient" artery, ${ }^{3}$ and were able to confirm that the phenomenon was indeed due to endothelial production of a humoral agent, EDRF, both tonically in the basal state and to a greater extent when stimulated, for example, by acetylcholine. By experiments in which we altered the transit time between donor and recipient vessels, we showed that EDRF is unstable, with a half life measured in seconds, ${ }^{3}$ though it is likely to be less than a second in vivo. ${ }^{4}$

EDRF: THE ENDOGENOUS NITROVASODILATOR

The possibility that EDRF might be nitric oxide emerged. ${ }^{5-7}$ Direct evidence for this was provided by Palmer and colleagues in $1987 . .^{8}$ There has, however, remained a suspicion that EDRF may be not nitric oxide itself but a closely related molecule. ${ }^{9}$ EDRF is thus the endogenous counterpart of the nitrovasodilator drugs. ${ }^{10}$ The metabolic step involved in the production of EDRF is that of activating nitric oxide synthase to provide nitric oxide from its precursor substrate, L-arginine, ${ }^{11}$ the supply of which seems not normally to be rate-limiting because it can be regenerated endogenously from other amino acids. The short half life of EDRF is thus explained, for nitric oxide is rapidly converted to nitrite and nitrate in the presence of water and oxygen, and even more rapidly by superoxide radicals, which are widely present in biological systems. ${ }^{1213}$

ERDF RELEASE

The list of conditions now known to stimulate EDRF release is large (for reviews, $s^{-e^{14-17}}$ ). It includes agents liberated during platelet aggregation and thrombosis (serotonin, ATP and ADP, thrombin) (thereby implying a further mechanism whereby healthy endothelium inhibits thrombosis) and a large number of hormones and neurotransmitter substances (for example, substance $P$, calcitonin gene 
related peptide, acetylcholine, noradrenaline, vasopressin, vasoactive intestinal peptide, bradykinin, histamine) (implying means whereby $(a)$ intravascular agents may transduce their signals across the endothelial barrier and (b) agents liberated from adventitial autonomic nerve endings on smaller arteries may exert their action after diffusion through to the endothelium). As an experimental tool, calcium ionophore can be used to stimulate EDRF release independently of receptors. Perhaps the most important physiological stimulant of EDRF release, though, is flow rate ${ }^{18}$ acting through the relatively small longitudinal shear force experienced uniquely by the endothelium-as confirmed by experiments with fluids of different viscosity ${ }^{19}$ and as increased with pulsatile flow. ${ }^{20}$

The mechanism of agonist stimulated release of EDRF from endothelial cells involves occupation of specific receptors, leading to activation of the phosphoinositol pathway and an increase in cytosolic calcium, ${ }^{21-28}$ both from release of internally stored calcium (which causes a transient high calcium level) and from continuing influx of extracellular calcium (which maintains a level of calcium sufficient to stimulate EDRF production but which is lower that that which would stimulate prostacyclin production). ${ }^{29}$ Shear force is thought to act through altering potassium conductance, leading by ionic interchange to an increase in cytosolic calcium. ${ }^{30-32}$ Calcium (via calcium calmodulin) activates nitric oxide synthase ${ }^{33}$ to produce EDRF. The stimulated production of EDRF is dependent also on the provision of mitochondrial ATP. ${ }^{34}$ Some negative feedback control exists in that EDRF activates soluble guanylate cyclase in endothelial as in other cells (see below) and thus inhibits its own production in response to some agonists. ${ }^{35} 36$

ACTION OF EDRF

Nitric oxide interacts with the haem moiety present in the cytosolic enzyme, soluble guanylate cyclase, to activate it and thereby raise intracellular concentrations of cyclic GMP. ${ }^{1037-40}$

An increased intracellular concentration of cyclic GMP inhibits the agonist induced activation of the phosphoinositol pathway, which is responsible for stimulating calcium influx and intracellular calcium release and thus for increasing cytosolic free calcium. ${ }^{41-44}$ An increase in cyclic GMP in vascular smooth muscle cells therefore relaxes vascular smooth muscle tone, particularly where this is increased by receptor mediated stimulation. ${ }^{45}$ It has analogous effects in other cell types-for example, platelets, myocardium (see below).

Haemoglobin also contains a haem moiety with which nitric oxide competitively interacts. ${ }^{4647}$ The sink of haemoglobulin within erythrocytes, ${ }^{48}$ as well as haemoglobin complexed to haptoglobin in plasma, ${ }^{49}$ ensure that EDRF has no downstream activity within the vascular compartment, as experimentally con- firmed. ${ }^{50}$ Its action is thus localised to the immediately subjacent vascular smooth muscle. Each millimetre of endothelium controls its own little bit of the vascular system.

VESSEL DIFFERENCES

EDRF activity has been demonstrated in every vessel studied-arteries, microvessels, and veins-and in every species studied, ${ }^{141617}$ with the implication that it is of primitive evolutionary origin. There are however considerable differences in the level of activity in different vessels. ${ }^{251-54}$ Differential bioassay has confirmed that these are due to differences both in the response to EDRF and in its release. ${ }^{55}$ These may be differences in basal release, flow related release, or release resulting from receptor stimulation, also with differences in specific receptor responsiveness. Differences in observed responses must also take account of differential baselines, as set by the levels of basal or flow related EDRF activity, because a "response" represents the difference between the starting level (baseline) and the end point (ceiling) of the response and will be as much influenced by the basal as by the stimulated level. ${ }^{256}$ Furthermore, many of the known stimulants of EDRF act not only on endothelial receptors but also on vascular smooth muscle receptors (not always of the same subtype). The resultant response to such a "double agent" will thus depend on the relative strengths of the EDRF mediated dilator response and the direct constrictor response. Clearly there is rich potential for variation in different blood vessels, and under different physiological conditions let alone pathological ones.

It has generally been considered that veins show lower EDRF activity than arteries. ${ }^{5157}$ Bioassay experiments have suggested that, at least in some cases, the difference may lie more in the response to EDRF than in its release. ${ }^{58} \mathrm{At}$ first sight, this runs counter to the generally held clinical view that the major site of action of its pharmacological analogue, the nitrovasodilator drugs, is on the venous system. ${ }^{59}$ This nitrovasodilator selectivity, however, probably reflects the need for most organic nitrovasodilator drugs, such as glyceryl trinitrate or the isosorbide nitrates, to undergo metabolic conversion to provide the active principle, nitric oxide, and veins seem better endowed with this metabolic pathway than arteries (while platelets seem to lack it entirely $)^{6061}$ - these considerations do not apply to molsidomine, SIN-1, or sodium nitroprusside which are sources of nitric oxide that do not depend on this metabolic step. Comparison of EDRF activity between different blood vessels is in practice difficult because the question is not as simple as it appears. Bioassay experiments have indeed confirmed the ability of veins (for example, human saphenous vein) to relax in response to EDRF ${ }^{62}$ and of human saphenous vein to produce EDRF. ${ }^{58}$ However, EDRF activity depends not only on EDRF production and the response to EDRF, but also on the specific agonists used to cause constriction and to stimulate EDRF release. Much of 
the apparent controversy in published reports is attributable to limitations inherent in the techniques used and to vessel specific differences between endothelial responsiveness to different agonists.

\section{Microvessels}

EDRF IN VIVO

Tonic microvascular EDRF activity has been demonstrated by infusing or feeding analogues of arginine which block nitric oxide production. In the intact rabbit, for example, this causes a substantial, prolonged but reversible increase in blood pressure-interestingly without calamitous platelet aggregation. ${ }^{63}$ Inhibition of coronary EDRF activity limits perfusion of isolated buffer perfused hearts to the point of inducing global ischaemia. ${ }^{64}$ In the human forearm, intra-arterial infusion of an arginine analogue likewise reduces flow, illustrating the contribution of tonic microvascular EDRF activity to the human circulation. ${ }^{65}$

EDRF AND FLOW IN VASCULAR NETWORKS The influence of EDRF activity on the coordinated behaviour of an intact microvascular bed has been investigated in the perfused rabbit ear, using microradiographic techniques to image simultaneously different generations of microvessels (down to about $100 \mu \mathrm{m}$ diameter) and observe their calibre in response to changes in flow in the presence and absence of EDRF activity. ${ }^{66-69}$ These studies illustrate the interdependence of different vessels within the bed and emphasise the need to consider the integrated behaviour of the whole vascular bed. For example, a pharmacologically induced increase in distal resistance can raise intravascular pressure and lead paradoxically to proximal dilatation, while a reduction of resistance in one part of a bed can lead to EDRF mediated dilatation as a result of increased flow throughout the bed.

Flow related EDRF activity amplifies a locally induced change in resistance in the bed, thus contributing, for example, to a metabolically mediated hyperaemic response. It also coordinates the changes in calibre throughout the bed. Furthermore, it reduces the increase in pressure needed to drive increased flow: specifically, flow (Q) was shown to be related to diameter (D) to the fourth power $\left(Q=a^{4}+b\right.$, where $a$ and $b$ are constants) when EDRF was present but not in its absence, implying that EDRF results in progressively reduced increments of pressure in order to increase flow at high flow rates. Moreover, EDRF activity was necessary to preserve constancy of flow distribution at different flow rates: in the absence of EDRF activity, flow distribution became heterogeneous-a form of "steal".

\section{BRANCHING GEOMETRY OF VASCULAR BEDS}

Analyses of vessel diameters in relation to flow in the rabbit ear preparation have shown that the pattern of branching angles in the bed provides for optimal minimisation of power losses-an optimality of design which is lost in the absence of EDRF activity. ${ }^{70}$

\section{AUTOREGULATION}

The "myogenic response", which is intrinsic to vascular smooth muscle in most beds, describes the constriction induced directly by an increase in intraluminal pressure. This is a positive feedback mechanism which makes for a potentially unstable situation unless balanced by an opposing positive feedback mechanism. EDRF may be seen as answering this need, for pressure is normally coupled to flow and increased flow leads to EDRF mediated vasodilatation, thus providing a positive feedback mechanism in the opposite direction.

The myogenic response is predominantly responsible for autoregulation of flow, whereby the flow is maintained relatively constant despite changing pressure within limits. EDRF opposes this phenomenon. The relative strength of these two mechanisms determines the degree of autoregulation, as appropriate to the biological needs of different beds. ${ }^{71}$

\section{PHYSIOLOGICAL IMPLICATIONS}

EDRF activity is high in the microvessels. In the intact network of the rabbit ear, it was particularly high in those vessels best placed to control distribution of flow (about 100-200 Am diameter) where calculated shear force was also highest. EDRF seems to have an important physiological role in maintaining "efficiency" of perfusion. Even minor impairment of EDRF activity would have adverse effects on the efficiency and work of perfusion.

\section{Platelets}

EDRF also increases cyclic GMP concentration in platelets. ${ }^{72-75}$ This inhibits both platelet adhesion and platelet aggregation, ${ }^{76}$ whereas agents that increase cyclic AMP (prostacyclin, adenosine) inhibit only aggregation. It is during adhesion that platelet derived growth factor (PDGF) is released. Cyclic GMP and cyclic AMP act at different sites within the cell and their effect on aggregation is synergistic. ${ }^{76}$

Activated platelets release agents (for example, serotonin, adenosine diphosphate (ADP) ) which stimulate intact endothelium to release EDRF; EDRF inhibits further platelet aggregation and causes local vasodilatation-a negative feedback. In the absence of endothelium, the direct action of these same agents causes further aggregation and local vasoconstriction-a positive feedback. Aggregation and constriction will thus be localised to the site of endothelial damage.

Platelets seem to have nitric oxide synthase themselves. ${ }^{77}$ Platelet activation is associated with nitric oxide production, and nitric oxide will activate soluble guanylate cyclase in the platelets to provide some negative feedback to the activation process. ${ }^{77}$

\section{Endocardium}

Endothelium also lines the much trabeculated cavity of the cardiac chambers. It has recently 
been shown that just as vascular endothelium influences vascular smooth muscle tone so endocardial endothelium can influence contraction of underlying cardiac muscle. ${ }^{78-82}$ Selective removal of endocardium from isolated papillary muscle preparations results in a "negative inotropic" effect which is unusual in that the duration of contraction is abbreviated but contractile behaviour early during the course of a contraction is unaltered. Effluent from cultured endocardial cells reverses this effect, thereby confirming that endocardium tonically releases a myocardial contraction prolonging factor (“endocardin"?) $80-82$ of as yet unknown identity. It does not seem to be any of the obvious candidates such as an endothelin or a prostaglandin. Preliminary experiments suggest that the tonic contraction-prolonging effect of endocardium which has been shown in isolated preparations is manifest also in the intact ventricle despite the small mass of endocardium relative to myocardium..$^{83}$ Clearly, this could be important in modulating diastolic filling. Conversely, endocardium can also be stimulated to release EDRF which increases cyclic GMP concentrations ${ }^{81} 828485$ in myocardium and, like other interventions which raise myocardial cyclic GMP, shortens the duration of contraction - an effect which is indistinguishable from that of removing endocardium (which does not itself alter cyclic GMP concentrations).

\section{Other sources of nitric oxide}

It is becoming evident that nitric oxide is an intercellular signal which fulfils a very wide variety of physiological roles. Many cell types other than endothelium also produce nitric oxide-platelets (see above), brain, ${ }^{86} 87$ adrenal cells, ${ }^{88}$ non-adrenergic non-cholinergic nerve fibres, ${ }^{89} 90$ neutrophils, monocytes, ${ }^{91}$ and mast cells ${ }^{92}$; while macrophages also produce nitric oxide as part of their immunological response but probably by a different mechanism..$^{934}$

\section{Pathophysiology}

There is a growing list of conditions in which EDRF activity seems to be impaired-including subarachnoid haemorrhage, ${ }^{95-98}$ endothelial damage and repair, ${ }^{99-102}$ ischaemia and reperfusion, atheroma, hypertension, diabetes, heart failure, lack of oestrogens, ${ }^{103}$ and aging. ${ }^{104} 105$ Conversely, increased EDRF production during endotoxin shock may be responsible for hypotension ${ }^{106}$ but also perhaps for survival. Endothelium, indeed, seems to be a prime target for "cardiovascular risk factors".

\section{SUBARACHNOID HAEMORRHAGE}

Subarachnoid haemorrhage is known to be complicated by cerebral vasoconstriction. Given that haemoglobin interacts with EDRF where it can get at it, an obvious potential mechanism is suggested. Several studies now provide convincing evidence that the constriction is indeed attributable to inhibition of EDRF activity by haemoglobin. ${ }^{95-98}$ Experimental in vivo injection of haemoglobin or whole blood into the subarachnoid space causes constriction of the intrathecal cerebral arteries associated with a reduction in their cyclic GMP content ( $\mathrm{T} M$ Griffith, unpublished observations). The effects persist for up to a week, with histological evidence of haemoglobin in the intimal layers. This probably reflects seepage through these intrathecal arteries, which are peculiar in that they have no vasa vasorum and may be more porous than other arteries.

\section{ENDOTHELIAL REGENERATION}

Several groups have studied the effects of balloon denudation of coronary arteries followed by regrowth. Endothelium regrows within about a week but interestingly this may be followed over subsequent months by progressive and selective impairment of receptor mediated EDRF responsiveness. ${ }^{9-102}$ These studies have important implications. Endothelial cells normally live for more than 10 years. They can obviously be kicked into rapid reproductive activity, however, by the crude insult of physical damage, after which they appear morphologically different ${ }^{99} 102$ and can exhibit altered function for up to six months. ${ }^{101}$ The selective impairment of EDRF responsiveness has been analysed further in the pig model, where the pattern of the impaired relaxation of coronary artery rings was shown to correspond to pertussis toxin sensitivity of these agonists and thus to dependence on a particular $G$ protein that couples receptor occupation to cell signalling. ${ }^{101} 107$ The endothelium seems to undergo an alteration of phenotypic expression, analogous to that which occurs in vascular smooth muscle where a change from normal contractile to synthetic phenotype underlies the proliferative growth intrinsic to atherogenesis and to the intimal hyperplasia seen after angioplasty and in graft stenosis.

\section{ISCHAEMIA AND REPERFUSION}

Ischaemia followed by reperfusion results in specific and probably prolonged impairment of EDRF responsiveness while endothelium independent responses remain unaltered. ${ }^{108-111}$ EDRF activity is not impaired after ischaemia alone but becomes impaired progressively during the early minutes of reperfusion. Most studies have used rather long periods (for example, $60 \mathrm{~min}$ ) of ischaemia, ${ }^{108} 109$ but impaired EDRF responses in conduit coronary arteries have been demonstrated after even 15 minutes in vivo ischaemia (which also alters microvascular endothelial function as evidenced by protein leak). ${ }^{112}$ Similar specific impairment of EDRF activity is evident in the coronary conduit and resistance vessels in the intact heart. The changes are probably secondary to mediators derived from reperfused ischaemic myocardium rather than reoxygenation of ischaemic endothelium itself, for endothelial cells in culture are remarkably resistant. Microvascular polymorph adhesion and plugging are known to occur during ischaemia and reperfusion. ${ }^{113}$ Neutrophil activation releases superoxide radicals and impairs EDRF activity. ${ }^{11415}$ If adhesion is prevented by 
specific antibodies, this sequence of events is prevented. ${ }^{116}$ Lymph draining ischaemic myocardium has been shown to contain agents chemotactic for polymorphs. ${ }^{117}$ Adenosine which increases neutrophil cyclic AMP content and inhibits superoxide production, ${ }^{118}$ can on the other hand ameliorate polymorph plugging and improve reflow. ${ }^{109}$ Conversely, intracoronary infusion of complement components can cause transient polymorph adhesion and plugging even in the absence of ischaemia. ${ }^{119}$ The suspicion is thus that oxygen free radicals are involved in this impairment of EDRF production and that they are derived predominantly from activated neutrophils in vivo.

Selective impairment of endothelium dependent relaxation evoked in vitro by aggregating platelets has been demonstrated for up to 12 weeks after reperfusion. ${ }^{110}$ Another consequence of impaired microvascular EDRF activity after reperfusion might be a redistribution of perfusion at the expense of the vulnerable endocardium. ${ }^{111}$

\section{ATHEROMA}

A wide range of hyperlipidaemic atheroma models, ranging from the rabbit to the primate and from hereditary to dietary hyperlipidaemia, have consistently shown impairment of receptor mediated EDRF responsiveness in large (for example, coronary) arteries while endothelium independent dilator and constrictor responses are preserved. ${ }^{120-127}$ It was at first thought that the layer of lipid deposition acted as a barrier interfering with EDRF diffusion to the underlying vascular smooth muscle, but it is now known that endothelial production of EDRF is impaired. The phenomenon is reversible though this takes as long as 18 months in the primate model ${ }^{123}$ and the abnormalities have persisted for 10 weeks in the rabbit model.

Does an insult to the endothelium also affect the less easily studied microvessels? As might have been predicted, abnormalities have now been reported also in the microvessels, specifically in respect of EDRF responsiveness to acetylcholine, bradykinin, and the calcium ionophore in coronary microvessels (100$200 \mu \mathrm{m}$ in diameter) whereas the endothelium independent response to adenosine and nitroprusside remained normal. ${ }^{128} 129$ The experimental hyperlipidaemia that is responsible for inducing atheroma-with intimal hyperplasia, "foam" cells, and fibrosis-in the large arteries clearly also impairs endothelial function in the microvessels, with potentially adverse consequences for the "efficiency" and homogeneity of flow distribution (see the section on coronary artery disease, below).

Conversely, feeding with fish oil may enhance EDRF activity. ${ }^{126130-133}$ We may expect to hear more of dietary manipulation of the lipid content of cell membranes and their influence on properties such as endothelial responsiveness to stimulants of EDRF activity.

\section{CORONARY ARTERY DISEASE}

Early experimental studies with coronary artery preparations where intact endothelium abolished conventional vasoconstrictor re- sponses had illustrated vividly how localised damage provided a model of non-specific localised constriction or "spasm". 2 Studies with clinical coronary artery disease have now produced an impressively consistent body of evidence showing that specific EDRF responsiveness is impaired in the large coronary arteries, as measured by angiographic calibre of these arteries in response to a number of interventions. Dose responses to the "double agent", acetylcholine, show a shift from dilatation in normal arteries towards increasing degrees of constriction in relation to graded severity of underlying atheroma, as evidenced by "irregularity" or "stenosis". 134135 A similar shift towards constrictor responses was observed in angiographically smooth arteries in relation to the presence of overt disease in other coronary arteries, ${ }^{136}$ or to the presence of known risk factors for atheroma, ${ }^{137}$ or indeed to age. ${ }^{105}$ The inference is that the EDRF mediated dilator response to acetylcholine is depressed in the presence of atheroma, of which angiographic evidence is an insensitive measure given the remodelling which preserves vessel calibre until the atheroma grows quite large. A similar shift from dilatation to constriction of upstream proximal arteries in relation to coexisting atheroma was seen in response to the increased flow through these large arteries induced by distal intracoronary injection of non-specific dilators such as papaverine or adenosine. ${ }^{136138}$ This shift in the response of proximal arteries was seen also with more physiological interventions such as exercise, ${ }^{139}$ the cold pressor test, ${ }^{140}$ or a pacing induced increase in heart rate. ${ }^{141}$

Interestingly, these two last interventions, which normally increase flow through the bed, decreased flow in the presence of non-critical upstream atheromatous stenosis, suggesting that there are corresponding changes in the responsiveness of resistance vessels. Recent studies by Drexler and colleagues provide further evidence of impaired microvascular EDRF responsiveness in the human coronary arterial bed: the increase in coronary flow induced by acetylcholine relative to that induced by endothelium independent dilatation with papaverine was found to be reduced in the presence of minor coronary artery disease and/or hypercholesterolaemia ${ }^{142}$ (and $\mathrm{H}$ Drexler, personal communication).

HYPERTENSION, DIABETES, SYNDROME X, HEART FAILURE, CARDIOMYOPATHY, VEIN GRAFTS

EDRF activity in large arteries can also be impaired in experimental ${ }^{143-145}$ and clinical ${ }^{146}$ hypertension and in diabetes..$^{147-149}$ Impaired EDRF activity may also contribute to impotence in diabetes. ${ }^{150}$ Both hypertension and diabetes are associated with "small vessel disease" and it is notable that the experimental combination of the two conditions can cause a form of "cardiomyopathy" that seems to be the result of focal necrosis of microvascular origin. ${ }^{151}$

The pathogenesis of microvascular angina (syndrome $\mathrm{X}$ ) remains unknown. ${ }^{152} \mathrm{~A}$ relative constrictor response to ergometrine has been 
described in some such patients, ${ }^{153}$ and ergometrine is another "double agent" which both stimulates EDRF release and exerts a direct constrictor action on vascular smooth muscle. ${ }^{154}$ It is legitimate to speculate on a possible role of impaired "feed-vessel" EDRF activity despite the limited therapeutic response to vasodilators in this condition ("lumped" pharmacological presentation of a drug may well achieve less effective dilatation than coordinated dilatation from flow stimulated release of an endogenous agent). ${ }^{155}$

EDRF activity in the systemic arteries has also now been reported to be impaired in heart failure ${ }^{156}$ and in the coronary bed in congestive cardiomyopathy. ${ }^{157}$ Conversely it has been reported to be increased by chronically elevated flow. ${ }^{158}$ It is also impaired after preparation of vein grafts. ${ }^{58}$

Endothelium seems indeed to be vulnerable to many insults, with potentially far reaching pathophysiological implications.

\section{A role in atherogenesis? LIPOPROTEINS}

Evidence is accumulating that low density lipoproteins (LDL) impair EDRF activity in vitro. ${ }^{159-161}$ LDL can directly inactivate EDRF, but it seems likely that oxidised LDL mediates a more important and longer lasting effect. In one study, the same adverse effect on EDRF responsiveness could be induced by lysolecithin at concentrations similar to those found in the oxidised LDL: it was suggested that alteration of the composition of the endothelial lipid membrane may influence receptor function for stimulation of EDRF release. ${ }^{162}$ LDL may be oxidised by, for example, endothelial cells, macrophages, or vascular smooth muscle cells in the arterial wall, there to be taken up by scavenger receptors on the macrophages where it accumulates to form foam cells and contribute to the atheroma. ${ }^{163}$

\section{LOCALISATION OF ATHEROMA}

The predilection of atheroma for certain sites implies haemodynamic influences in the process, the signal for which is thus likely to be mediated by the endothelium. The weight of evidence now points strongly to localisation of atheroma at sites of low shear stress. ${ }^{164}$ In speculating on the possible role of EDRF in localising atheroma, two experimental observations may be relevant.

Transport of lipoproteins across vessel walls will depend on their intravascular concentration, driving pressure, wall thickness, and wall "permeability". As an example of this last determinant, Caro and Lever showed that nitrovasodilators enhanced mass transport of particles across large artery walls ${ }^{165}$ : fewer particles accumulated on the intimal side of the media as the lattice of the medial smooth muscle was relaxed, with, by implication, faster transit across the wall. For particles, read LDL and for nitrovasodilators, read EDRF. EDRF activity is increased by high shear stress. High shear stress, via EDRF, could thus reduce the transit time of LDL across the arterial wall and the opportunity for oxidation en route. More recent work indicates that LDL moves less freely through the arterial wall than albumin, and that high transmural pressure greatly increases LDL concentrations in the intima, ${ }^{166}$ adding further to the view that the media acts as a molecular sieve for LDL. ${ }^{167}$ The second experimental observation derives from simple experiments in which wrapping foil around a blood vessel leads to the rapid development of atheroma. ${ }^{168}$ One possible explanation for this is that the foil somehow prevents the egress of LDL from the adventitial surface of the vessel thereby contributing to its accumulation.

\section{ENDOTHELIAL DAMAGE/DYSFUNCTION}

Endothelial damage has long been held to be important in the atherogenic process, ${ }^{169}$ though opponents of the hypothesis have drawn attention to the relative lack of histological evidence for endothelial damage. It is notable too that localised experimental removal of endothelium which does not damage the underlying vessel wall does not induce intimal hyperplasia. ${ }^{170}$ Conversely, continuing minor endothelial damage as from an indwelling catheter does induce intimal hyperplasia. ${ }^{171}$ It seems that the normal repair process after an episode of endothelial injury is self limiting, whereas prolonged stimulation of repair from recurrent endothelial damage perpetuates a chronic inflammatory response which results in the atheromatous lesion.

Endothelial cells normally divide only rarely, but they can be stimulated to divide rapidly to re-cover a denuded area. Such recently regrown cells have a somewhat different morphological appearance and their function (as manifest for example by altered EDRF responsiveness) remains abnormal for long periods. It has now been shown that other insults that fall short of causing actual denudation also result in prolonged dysfunction, associated generally with some alteration of morphological appearance. The evidence suggests that endothelium can undergo phenotypic modulation in response to several adverse stimuli, as for example the cytotoxic action of oxidised LDL. A central role of endothelium in atherogenesis might then be dependent on such phenotypic alteration, rather than on actual damage itself. Whether the altered phenotypic expression represents a single functional state characterised by both cell division and a pattern of altered function, or whether there can be variations on this theme (that is, a spectrum of altered phenotypes), remains unknown. Likewise it is not clear whether the altered state necessarily reflects the response of neighbouring endothelial cells to cryptic cell loss, or whether it can be the direct response of endothelial cells to adverse stimuli that fall short of causing actual cell death.

Reduced EDRF responsiveness is thus likely to be but one manifestation of altered endothelial function-a marker of an altered state which has other atherogenic characteristics, as for example by increasing leucocyte adhesion and attracting and promoting growth of underlying cells, leading to the atheroma which 
has many characteristics of a chronic local inflammatory response.

Reduced EDRF activity itself, however, could have far reaching effects which might contribute to the atherogenic process. Nitric oxide is an oxygen radical scavenger. Less nitric oxide implies more superoxide, with greater propensity to oxidise LDL as well as contribute to further cell dysfunction. Less EDRF implies less porosity of the arterial wall and longer transit time, offering greater opportunity for oxidation en route. Less EDRF implies less inhibition of platelet adhesion with its consequent very localised release of platelet derived growth factor (which may then contribute to the cascade of events underlying intimal proliferation and atheroma). Less EDRF also means lower concentrations of cyclic GMP in the artery wall, and cyclic GMP exerts antiproliferative effects in some preparations of vascular smooth muscle cells, ${ }^{172-174}$ possibly in relation to whether they are in the contractile or synthetic phenotype. ${ }^{175}$

\section{An integrated system}

A lecture such as this offers a rare opportunity for indulging in an overview of the field that seeks to discern form emerging through the mists of uncertainty which always lie ahead. Technical developments that allow us to measure and analyse flow have coincided with new conceptual insights into its control. We have moved from a cardiovascular preoccupation with pressure, faute de mieux, to an era in which we are seeing an accelerating exploration of the complexities of flow. Flow after all is what the circulation is all about. It has become clear that endothelium, sited at the interface between flowing blood and the vessel wall, plays a key role in controlling vascular structure as well as tone. Future cardiovascular physicians will surely look back on the present surge in our understanding of the vascular system as a major chapter in the evolution of our specialty of cardiovascular medicine.

AHH, who holds the Sir Thomas Lewis British Heart Founda tion Chair of Cardiology in the University of Wales College of Medicine, gratefully acknowledges the help of $\mathrm{Dr} A \mathrm{C}$ Newby, Dr M J Lewis, and Dr T M Griffith in the preparation of this lecture.

1 Furchgott RF, Zawadski JV. The obligatory role of endothelial cells in the relaxation of arterial smooth muscle by acetylcholine. Nature 1980;288:373-6.

2 Griffith TM, Henderson AH, Hughes Edwards D, Lewis MJ. Isolated perfused rabbit coronary artery and aortic strip preparations: the role of endothelium-derived relaxstrip preparations: the role of endothelium-de
ant factor. J Physiol (Lond) 1984;351:13-24.

3 Griffith TM, Edwards DH, Lewis MJ, Newby AC, Henderson AH. The nature of endothelium-derived vascular derson AH. The nature of endothelium-der.

$4 \mathrm{Kelm}$ M, Schrader J. Control of coronary vascular tone by nitric oxide. Circ Res 1990;66:1561-75.

5 Ignarro LJ, Byrns RE, Bugam GM, Wood KS. Endothelium-derived relaxing factor from pulmonary artery and vein possesses pharmacologic and chemical properties identical to

6 Khan MT, Furchgott RF. Similarities of behaviour of nitric oxide (NO) and endothelium-derived relaxing factor in a perfusion cascade bioassay system [Abstract]. Fed Proc 1987;46:385.

7 Ignarro LJ. Biological actions and properties of endothelium-derived nitric oxide formed and released from artery and vein. Circ Res 1989;65:1-21

8 Palmer RMJ, Ferrige AG, Moncada S. Nitric oxide release accounts for the biological activity of endothelium derived relaxing factor. Nature 1987;327:524-6.
9 Myers PR, Minor RL, Guerra R Jr, Bates JN, Harrison DG. Vasorelaxant properties of the endothelium-derived relaxing factor more closely resemble S-nitrosocysteine than nitric oxide. Nature 1990;345:161-3.

10 Katsuki H, Amold W, Mittal C, Murad F. Stimulation of guanylate cyclase by sodium nitroprusside, nitroglycerin
and nitric oxide in various tissue preparations and comparison to the effects of sodium azide and hydroxycomparison to the effects of sodium azide and

11 Palmer RMJ, Ashton DS, Moncada S. Vascular endothelial cells synthesize nitric oxide from L-arginine. Nature 1988;333:664-6.

12 Gryglewski RJ, Palmer RMJ, Moncada S. Superoxide anion is involved in the breakdown of endotheliumderived vascular relaxing factor. Nature 1986;320:454-6.

13 Rubanyi GM, Vanhoutte PM. Superoxide and hyperoxia inactivate endothelium-derived relaxing factor. $A m J$ Physiol 1986;250:H822-7.

14 Furchgott RF. Role of endothelium in responses of vascular smooth muscle. Circ Res 1983;53:557-73.

15 Furchgott RF. The role of endothelium in the responses of vascular smooth muscle to drugs. Annu Rev Pharmacol Toxicol 1984;24:175-97.

16 Griffith TM, Lewis MJ, Newby AC, Henderson AH. Endothelium-Derived Relaxing Factor. J Am Coll Cardiol 1988;12:797-806.

17 Angus JA, Cocks TM. Endothelium-derived relaxing Angus JA, Cocks TM. Endothelium-der
factor. Pharmacol Ther 1989;41:303-52.

18 Holtz J, Forstermann U, Pohl U, Giesler M, Bassenge E. Flow-dependent, endothelium-mediated dilatation of epicardial coronary arteries in conscious dogs: effects of cyclooxygenase inhibition. $J$ Cardiovasc Pharmacol 1984;6:1161-9.

19 Melkumyants AM, Balashov SA. Effect of blood viscosity on arterial flow induced dilator response. Cardiovasc Res 1990;24:165-8.

20 Pohl U, Busse R, Kuon E, Bassenge E. Pulsatile perfusion stimulates the release of endothelial autocoids. J Appl Cardiol 1986;1:215-35.

21 Lambert TL, Kent RS, Whorton AR. Bradykinin stimulation of inositol polyphosphate production in porcine
aortic endothelial cells. J Biol Chem 1986;261:15288-93.

22 Derian CK, Moskowitz MA. Polyphosphoinositide hydrolysis in endothelial cells and carotid artery endothelial cells and carotid artery segments. J Biol Chem 1986;261:3831-7.

23 Hallam TJ, Pearson JD. Exogenous ATP raises cytoplasmic free calcium in fura-2 loaded piglet aortic endoplasmic free calcium in fura-2 loaded pi

24 Colden-Stanfield M, Schilling WP, Ritchie AK, Eskin SG, Navarro LT, Kunze DL. Bradykinin-induced increases in cytosolic calcium and ionic currents in cultured bovine aortic endothelial cells. Circ Res 1987;61:632-40.

25 Jacob R, Merritt JE, Hallam TJ, Rink TJ. Repetitive spikes in cytoplasmic calcium evoked by histamine in human endothelial cells. Nature 1988;335:40-5.

26 Loeb AL, Izzo NJ, Johnson AM, Garrison JC, Peach MJ. Endothelium-derived relaxing factor release associated with increased endothelial cell inositol triphosphate and intracellular calcium. Am J Cardiol 1988;62:36G-40G.

27 Pollock WK, Wreggett KA, Irvine RF. Inositol phosphate production and $\mathrm{Ca}^{2+}$ mobilization in human umbilicalvein endothelial cells stimulated by thrombin and hisvein endothelial cells stimulated by

28 Newby AC, Henderson AH. Stimulus-secretion coupling in vascular endothelial cells. Annu Rev Physiol 1990; in vascular

29 White DG, Martin W. Differential control and calciumdependence of production of endothelium-derived relaxing factor and prostacyclin by pig aortic endothelial cells. Br J Pharmacol 1989;97:683-90.

30 Lansman JB, Hallam TJ, Rink TJ. Single stretch-activated ion channels in vascular endothelial cells as mechanotransducers. Nature 1987;325:811-3.

31 Olesen SP, Clapham DE, Davies PF. Haemodynamic shear stress activates a $\mathrm{K}^{+}$current in vascular endothelial cells. Nature 1988;331:168-70.

32 Lansman JB. Going with the flow. Nature 1988;331:481-2.

33 Bredt DS, Snyder SH. Isolation of nitric oxide synthetase, a calmodulin-requiring

34 Griffith TM, Edwards DH, Newby AC, Lewis MJ. Production of endothium-derived relaxant factor is dependent on oxidative phosphorylation and extracellular calcium. Cardiovasc Res 1986;20:7-12.

35 Evans HG, Smith JA, Lewis MJ. Release of endotheliumderived relaxing factor (EDRF) is inhibited by 8-bromoderived relaxing factor (EDRF) is inhibited by 8-brom
cyclic GMP. J Cardiovasc Pharmacol 1988;12:672-7.

36 Hogan JC, Smith JA, Richards AC, Lewis MJ. Atrial Hogan JC, Smith JA, Richards AC, Lewis MJ. Atrial
natriuretic peptide inhibits EDRF release from blood vessels of the rabbit. Eur J Pharmacol 1989;165:129-34.

37 Rapoport RM, Draznin MB, Murad F. Endotheliumdependent relaxation in rat aorta may be mediated through cyclic GMP-dependent protein phosphorylation. Nature 1983;306:174-6.

38 Ignarro LJ, Burke IM, Wood KS, Wolin MS, Kadowitz PJ. Association between cyclic GMP accumulation and acetylcholine-elicited relaxation of bovine intrapulmonary artery. J Pharmacol Exp Ther 1984;228:682-90.

39 Griffith TM, Edwards DH, Lewis MJ, Henderson AH. Evidence that cyclic guanosine monophosphate (cGMP) mediates endothelium-dependent relaxation. Eur J Pharmacol 1985;112:195-202.

40 Forstermann U, Mulach A, Bohme E, Busse R. Stimulation of soluble gianylate cyclase by an acetylcholine- 
induced endothelium-derived factor from rabbit and canine arteries. Circ Res 1986;58:531-8.

41 Rapoport RM. Cyclic guanosine monophosphate inhibition of contraction may be mediated through inhibition of phosphotidylinositol hydrolysis in rat aorta. Circ Res 1986;58:407-10.

42 Lang D, Lewis MJ. Endothelium-derived relaxing factor inhibits the formation of inositol triphosphate by rabbit aorta. J Physiol (Lond) 1989;411:45-52.

43 Collins P, Griffith TM, Henderson AH, Lewis MJ. Endothelium-derived relaxing factor alters calcium fluxes in rabbit aorta: a cyclic guanosine monophosphatemediated effect. J Physiol (Lond) 1986;381:427-37.

44 Morgan JP, Morgan KG. Alteration of cytoplasmic ionised calcium levels in smooth muscle by vasodilators in the ferret. J Physiol (Lond) 1984;357:539-51.

45 Collins P, Henderson AH, Lang D, Lewis MJ. Endothelium-derived relaxing factor and nitroprusside compared in noradrenaline- and $\mathrm{K}^{+}$-contracted rabbit and rat aortae. J Physiol (Lond) 1988;400:395-404.

46 Martin W, Villani GM, Jothianandan D, Furchgott RF. Selective blockade of endothelium-dependent and glyceryl trinitrate-induced relaxation by haemoglobin glyceryl trinitrate-induced relaxation by haemoglobin axp Ther 1985;232:708-16.

47 Martin W, Smith JA, White DG. The mechanisms by which haemoglobin inhibits the relaxation of rabbit aorta induced by nitrovasodilators, nitric oxide, or bovine retractor penis inhibitory factor. Br J Pharmacol 1986; 89:563-71.

48 Evans HG, Ryley HC, Hallett I, Lewis MJ. Human red blood cells inhibit endothelium-derived relaxing factor (EDRF) activity. Eur J Pharmacol 1989;163:361-4.

49 Edwards DH, Griffith TM, Ryley HC, Henderson AH. Haptoglobin-haemoglobin complex in human plasma inhibits endothelium-dependent relaxation: evidence that endothelium derived relaxing factor acts as a local that endothelium derived relaxing factor

50 Angus JA, Campbell GR, Cocks TM, Manderson JA. Vasodilatation by acetylcholine is endothelium-dependent: a study by sonomicrometry in canine femoral artery in vivo. J Physiol (Lond) 1983;344:209-22.

51 De Mey JG, Vanhoutte PM. Heterogeneous behavior of the canine arterial and venous wall. Circ Res 1982;51:439-47.

52 Collins P, Chappell SP, Griffith TM, Lewis MJ, Henderson AH. Differences in basal endothelium-derived relaxing factor activity in different artery types. $J$ Cardiovasc Pharmacol 1986;8:1158-62.

53 Seidel CL, LaRochelle J. Venous and arterial endothelia: different dilator abilities in dog vessels. Circ Res 1987; 60:626-30.

54 Christie MI, Griffith TM, Lewis MJ. A comparison of basal and agonist-stimulated release of endothelium-derived relaxing factor from different arteries. $\mathrm{Br} J$ Pharmacol 1989;98:397-406.

55 Christie MI, Lewis MJ. Vascular smooth muscle sensitivity to endothelium-derived relaxing factor is different

56 White DG, Lewis MJ, Griffith TM, Henderson AH Influence of endothelium on drug-induced relaxation of the rabbit aorta. Eur J Pharmacol 1986;121:19-23.

57 Thom S, Hughes A, Martin G, Sever PS. Endotheliumdependent relaxation in isolated human arteries and veins. Clin Sci 1987;73:547-52.

58 Angelini GD, Christie MI, Bryan AJ, Lewis MJ. Surgical preparation impairs release of endothelium-derived relaxing factor from human saphenous vein. Ann Thorac Surg 1989;48:417-20.

59 Rosen R, Konig E, Klaus W. Different sensitivities of arteries and veins to glyceryltrinitrate-induced relaxation arteries and veins to glyceryltrinitrate-induced relaxation rabbits. Arch Int Pharmacodyn 1987;285:226-37.

60 Kawamoto JH, McLaughlin BE, Brien JF, Marks GS, Nakatsu K. Biotransformation of glyceryl trinitrate and elevation of cyclic GMP precede glyceryl trinitrateinduced vasodilation. J Cardiovasc Pharmacol 1990;15: 714-9.

61 Benjamin N, Dutton JAE, Ritter JM. Potentiation of antiaggregatory effect of glyceryl trinitrate with cultured vascular smooth muscle cells [Abstract]. Arch Int Pharmacodyn Ther 1990;305:230.

62 Luscher TF, Diederich D, Siebenmann R, et al. Difference between endothelium-dependent relaxations in arterial and in venous coronary bypass grafts. $N$ Engl $\mathrm{J} \mathrm{Med}$ 1988;319:462-7.

63 Rees DD, Palmer RMJ, Moncada S. Role of endotheliumderived nitric oxide in the regulation of blood pressure. derived nitric oxide in the regulation of b
Proc Natl Acad Sci USA 1989;86:3375-8.

64 Amezcua JL, Palmer RMJ, de Souza BM, Moncada S. Nitric oxide synthesized from $L$-arginine regulates vascular tone in the coronary circulation of the rabbit. $\mathrm{Br} J$ Pharmacol 1989;97:1119-24.

65 Vallance P, Collier J, Moncada S. Effects of endotheliumderived nitric oxide on peripheral arteriolar tone in man. Lancet 1989;8670:997-1000.

66 Griffith TM, Edwards DH, Davies RL, Harrison TJ, Evans KT. EDRF coordinates the behaviour of vascular resistance vessels. Nature 1987;329:442-5.

67 Griffith TM, Edwards DH, Davies RL, Harrison TJ, Evans $\mathrm{KT}$. Endothelium-derived relaxing factor (EDRF) and resistance vessels in an intact vascular bed: a microangiographic study of the rabbit isolated ear. Br J Pharmacol 1988;93:654-62.

68 Griffith TM, Henderson AH. EDRF and the regulation of vascular tone. Int J Microcirc 1989;8:383-96.
69 Griffith TM, Edwards DH, Davies RL, Henderson AH. The role of EDRF in flow distribution: a microangiographic study of the rabbit isolated ear. Microvasc Res 1989;37:162-77.

70 Griffith TM, Edwards DH. Basal EDRF activity helps to keep the geometrical configuration of arterial bifurcations close to the Murray optimum. J Theor Biol 1990, close to the

71 Griffith TM, Edwards DH. Myogenic autoregulation of flow may be inversely related to endothelium-derived relaxing factor activity. $A m J$ Physiol 1990;258: H1171-80.

72 Hogan JC, Lewis MJ, Henderson AH. In vivo EDRF activity influences platelet function. $\mathrm{Br} J$ Pharmacol 1988;94:1020-2.

73 Ayuma H, Ishikawa M, Sakiyaki S. Endothelium-dependent inhibition of platelet aggregation. $\mathrm{Br} J$ Pharmacol 1986;80:411-5.

74 Furlong B, Henderson AH, Lewis MJ, Smith JA. Endothelium-derived relaxing factor inhibits in vitro platelet thelium-derived relaxing factor inhibits in vitro

75 Pohl U, Busse R. EDRF increases cyclic GMP in platelets during passage through the coronary vascular bed. Circ Res 1989;65:1798-803.

76 Radomski MW, Palmer RMJ, Moncada S. The role of nitric oxide and cGMP in platelet adhesion to vascular endothelium. Biochem Biophys Res Commun 1987; 148:1482-9.

77 Radomski MW, Palmer RMJ, Moncada S. L-arginine nitric oxide pathway present in human platelets regulates aggregation. Proc Natl Acad Sci USA 1990;87:5193-7.

78 Brutsaert DL, Meulemans AL, Sipido KR, Sys SU. Effects of damaging the endocardial surface on the mechanical performance of isolated cardiac muscle. Circ Res 1988;62:358-66.

79 Brutsaert DL. The endocardium. Annu Rev Physiol 1989; 51:263-73.

80 Lewis MJ, Shah AM, Smith JA, Henderson AH. Does endocardium modulate myocardial contractile performance? Cardioscience 1990;1:83-7.

81 Shah AM, Smith JA, Lewis MJ. The role of endocardium in the modulation of contraction of isolated papillary muscles of the ferret. J Cardiovasc Pharmacol 1991 (in press).

82 Smith JA, Shah AM, Lewis MJ. Cultured endocardial cells release factors which modulate myocardial contractile performance [Abstract]. Eur Heart J 1990;11 (Abstract suppl):78.

83 Gillebert TC, De Hert SG, Andries LJ, Jagenau AH, Brutsaert DL. Altering endocardial function by ultrasound modulates left ventricular performance [Abstract] Eur Heart J 1990;11 (Abstract suppl):79.

84 Shah AM, Lewis MJ, Henderson A. Elevating cyclic GMP mimics the characteristic negative inotropic effect of mimics the characteristic negative inotropic

85 Shah AM, Lewis MJ, Henderson A. Endocardial control of myocardial contraction [Abstract]. J Moll Cell Cardio 1989;21(suppl III):S23

86 Garthwaite J, Charles SL, Chess-Williams R. Endothelium-derived relaxing factor release on activation of NMDA receptors suggests role as intercellula messenger in the brain. Nature 1988;336:385-8.

87 Knowles RG, Palacios M, Palmer RMJ, Moncada S. Formation of nitric oxide from $L$-arginine in the central nervous system: a transduction mechanism for stimulation of the soluble guanylate cyclase. Proc Natl Acad $S_{c i}$ US A 1989;86:5159-62.

88 Palacios M, Knowles RG, Palmer RMJ, Moncada S. Nitric oxide from $L$-arginine stimulates the soluble guanylate cyclase in adrenal glands. Biochem Biophys Res Commun cyclase in adrenal

89 Gillespie JS, Liu XR, Martin W. The effects of L-arginine and NG-monomethyl L-arginine on the response of the rat anococcygeus muscle to NANC nerve stimulation. $B$ $J$ Pharmacol 1989;98:1080-2.

90 Bult H, Boeckxstaens GE, Pelckmans PA, Jordaens FH, Van Maercke YM, Herman AG. Nitric oxide as an inhibitory non-adrenergic non-cholinergic neurotransmitter. Nature 1990;345:346-7.

91 McCall T, Boughton-Smith NK, Palmer RMJ, Whittle BJR, Moncada S. Synthesis of nitric oxide from Larginine by neutrophils. Release and interaction with superoxide anion. Biochem $J$ 1989;261:293-6.

92 Salvemini D, Masini E, Anggard E, Mannaioni PF, Vane J. Synthesis of a nitric oxide-like factor from $L$-arginine by rat serosal mast cells: stimulation of guanylate cyclase and inhibition of platelet aggregation. Biochem Biophys Res Comm 1990;169:596-601.

93 Hibbs JB Jr, Vavrin Z, Taintor RR. L-arginine is required for expression of the activated macrophage effector for expression of the activated macrophage effector mechanism causing selective metabolic

94 Marletta MA, Yoon PS, Iyengar R, Leaf CD, Wishnok JS Macrophage oxidation of $L$-arginine to nitrite and nitrate: nitric oxide is an intermediate. Biochemistry 1988;27:8706-11.

95 Kassell NF, Sasaki T, Colohan ART, Nazar G. Cerebral vasospasm following aneurysmal subarachnoid hemorrhage. Stroke 1985;16:562-72.

96 Nakagomi T, Kassell NF, Sasaki T, Fujiwara S, Lehman RM, Torner JC. Impairment of endothelium-dependent vasodilation induced by acetylcholine and adenosine triphosphate following experimental subarachnoid hemorrhage. Stroke 1987;18:482-9.

97 Kanamaru K, Waga S, Kojima T, Fujimoto K, Niwa S. 
Endothelium-dependent relaxation of canine basilar arteries. Part 1 . Inhibition by hemoglobin and cerebrospinal fluid from patients with aneurysmal subarachnoid hemorrhage. Stroke 1987;18:938-43.

98 Byrne JV, Griffith TM, Edwards DH, Harrison TJ, Johnston KR. Investigation of the vasoconstrictor action of subarachnoid haemoglobin in the pig cerebral circulation in vivo. Br J Pharmacol 1989;97:669-74.

99 Shimokawa H, Aarhus LL, Vanhoutte PM. Porcine coronary arteries with regenerated endothelium have a reduced endothelium-dependent responsiveness to aggregating platelets and serotonin. Circ Res 1987;61:256-70.

100 Yamamoto Y, Tomoike H, Egashira K, Kobayashi $T$, Kawasaki T, Nakamura M. Pathogenesis of coronar artery spasm in miniature swine with regional intimal thickening after balloon denudation. Circ Res 1987; 60:113-21.

101 Shimokawa H, Flavahan NA, Vanhoutte PM. Natura course of the impairment of endothelium-dependen relaxations after balloon endothelium removal in porcin coronary arteries. Circ Res 1989;65:740-53.

102 Weidinger FF, McLenachan JM, Cybulsky MI, et al. Persistent dysfunction of regenerated endothelium after balloon angioplasty of rabbit iliac artery. Circulation 1990;81:1667-79.

103 Gisclard V, Miller VM, Vanhoutte PM. Effect of $17 \beta$ Estradiol on endothelium-dependent responses in the Estradiol on endothelium-dependent respon

104 Moritoki H, Tanioka A, Maeshiba Y, Iwamoto T, Ishida Y, Araki $\mathrm{H}$. Age-associated decrease in histamine-induced vasodilatation may be due to reduction of cyclic GMP formation. Br J Pharmacol 1988;95:1015-22.

105 Yasue H, Matsuyama K, Matsuyama K, Okumura K, Morikami Y, Ogawa H. Responses of angiographically normal human coronary arteries to intracoronary injection of acetylcholine by age and segment. Circulation 1990;81:482-90.

106 Salvemini D, Korbut R, Anggard E, Vane J. Immediate release of a nitric oxide-like factor from bovine aortic endothelial cells by Escherichia coli lipopolysaccharide. Proc Natl Acad Sci USA 1990;87:2593-7.

107 Shimokawa H, Flavahan NA, Shepherd JT, Vanhoutte PM. Endothelium-dependent inhibition of ergonovineinduced contraction is impaired in porcine coronary induced contraction is impaired in porcine coronary arteries with

108 VanBenthuysen KM, McMurtry IF, Horwitz LD. Reperfusion after acute coronary occlusion in dogs impairs endothelium-dependent relaxation to acetylcholine and augments contractile reactivity in vitro. J Clin Invest 1987;79:265-74.

109 Olafsson B, Forman MB, Puett DW, et al. Reduction of reperfusion injury in the canine preparation by intracoronary adenosine: importance of the endothelium and the no-reflow phenomenon. Circulation 1987;76: 1135-45.

110 Pearson PJ, Schaff HV, Vanhoutte PM. Long-term impairment of endothelium-dependent relaxations to aggregating platelets aftor reperfusion injury in canine coronary arteries. Circulation 1990;81:1921-7.

111 Pelc LR, Garancis JC, Gross GJ, Warltier DC. Alteration of endothelium-dependent distribution of myocardial blood flow after coronary occlusion and reperfusion blood flow after coronary occ

112 Dauber IM, VanBenthuysen KM, McMurtry IF, et al. Functional coronary microvascular injury evident as increased permeability due to brief ischaemia and reperfusion. Circ Res 1990;66:986-98.

113 Lucchesi BR, Mullani KM. Leukocytes and ischemiainduced myocardial injury. Annu Rev Pharmacol Toxicol 1986;26:573-81.

114 Ohlstein EH, Nichols AJ. Rabbit polymorphonuclear neutrophils elicit endothelium-dependent contraction in vascular smooth muscle. Circ Res 1989;65:917-24.

115 Nishida M, Kuzuya T, Hoshida S, et al. Endothelia production of vasoconstrictive factors augmented by polymorphonuclear leukocytes [Abstract]. Circulation polymorphonuclear leuk

116 Carden DL, Smith JK, Korthuis RJ. Neutrophil-mediated microvascular dysfunction in postischemic canine microvascular dysfunction in postisch

117 Dreyer WJ, Smith CW, Michael LH, et al. Canine neutrophil activation by cardiac lymph obtained durin reperfusion of ischemic myocardium. Circ Res 1989; 65:1751-62.

118 Cronstein BN, Levin RI, Belanoff J, Weissman G, Hirschhorn R. Adenosine: an endogenous inhibitor of neutrophil-mediated injury to endothelial cells. $J$ Clin Invest 1986;78:760-70.

119 Martin SE, Chenoweth DE, Engler RL, Roth DM Longhurst JC. C5a decreases regional coronary blood flow and myocardial function in pigs: implications for a granulocyte mechanism. Circ Res 1988;63:483-91.

120 Verbeuren TJ, Jordaens FH, Zonnekeyn LL, Van Hove CE, Coene MC, Herman AG. Effect of hypercholesterolaemia on vascular reactivity in the rabbit. Circ Res 1986;58:552-64

121 Freiman PC, Mitchell GG, Heistad DD, Armstrong ML, Harrison DG. Atherosclerosis impairs endothelium dependent vascular relaxation to acetylcholine and thrombin in primates. Circ Res 1986;58:783-9.

122 Jayakody L, Senaratne $M$, Thomson A, Kappagoda $T$ endothelium-dependent relaxation in experimental atherosclerosis in the rabbit. Circ Res 1987;60:251-64.

123 Heistad DD, Mark AL, Marcus ML, Piegors DJ, Arm- strong ML. Dietary treatment of atherosclerosis abolishes hyperresponsiveness to serotonin: implications for vasospasm. Circ Res 1987;61:346-51.

124 Shimokawa H, Kim P, Vanhoutte PM. Endotheliumdependent relaxation to aggregating platelets in isolated basilar arteries of control and hypercholesterolemic pigs. Circ Res 1988;63:604-12.

125 Cohen RA, Zitnay KM, Haudenschild CC, Cunningham LD. Loss of selective endothelial cell vasoactive functions caused by hypercholesterolemia in pig coronary arteries. Circ Res 1988;63:903-10.

126 Koromori K, Shimokawa H, Vanhoutte PM. Endothelium-dependent relaxation in response to aggregating platelets in porcine femoral veins and its modulation by diet. Circulation 1989;80:401-9.

127 Kolodgie FD, Virmani R, Rice HE, Mergner WJ. Vascular reactivity during the progression of atherosclerotic plaque. A study in watanabe heritable hyperlipidemic rabbits. Circ Res 1990;66:1112-26.

128 Sellke FW, Armstrong ML, Harrison DG. Endotheliumdependent vascular relaxation is abnormal in the coronary microcirculation of atherosclerotic primates. Circulation 1990;81:1586-93.

129 Chilian WM, Dellsperger KC, Layne SM, et al. Effects of atherosclerosis on the coronary microcirculation. $\mathrm{Am} \mathrm{J}$ Physiol 1990;258:H529-39.

130 Shimokawa $H$, Vanhoutte P. Dietary $\omega 3$ fatty acids and endothelium-dependent relaxations in porcine coronary arteries. Am J Physiol 1989;256:H968-73.

131 Sassen LMA, Hartog JM, Lamers JMJ, Klompe M, Van WLJ, Verdouw PD. Mackerel oil and atherosclerosis in pigs. Eur Heart J 1989;10:838-46.

132 Goodnight SH. The vascular effects of $\omega-3$ fatty acids. Invest Dermatol 1989;93:102S-6S.

133 Vekshtein VI, Yeung AC, Vita JA, et al. Fish oil improves endothelium-dependent relaxation in patients with coronary artery disease [Abstract]. Circulation 1989; 80(suppl II):434.

134 Ludmer PL, Selwyn AP, Shook TL, et al. Paradoxical vasoconstriction induced by aectylcholine in atherosclerotic coronary arteries. $N$ Engl J Med 1986;315: 1046-51.

135 Horio Y, Yasue H, Rokutanda M, et al. Effects of intracoronary injection of acetylcholine on coronary arterial diameter. Am J Cardiol 1986;57:984-9.

136 Cox DA, Vita JA, Treasure CB, et al. Atherosclerosis impairs flow-mediated dilation of coronary arteries in humans. Circulation 1989;80:458-65.

137 Vita JA, Treasure CB, Nabel EG, et al. Coronary vasomotor response to acetylcholine relates to risk factors for coronary artery disease. Circulation 1990;81:491-7.

138 Drexler $\mathrm{H}$, Zeiher AM, Wollschlager $\mathrm{H}$, Meinertz T, Just $\mathrm{H}$, Bonzel T. Flow-dependent coronary artery dilatation in humans. Circulation 1989;80:466-74.

139 Gordon JB, Ganz P, Nabel EG, Fish D, Zebede J, Mudge GH. Atherosclerosis influences the vasomotor response of epicardial coronary arteries to exercise. J Clin Invest 1989;83:1946-52.

140 Nabel EG, Ganz P, Gordon JB, Alexander RW, Selwyn AP. Dilation of normal and constriction of atheroAP. Dilation of normal and constriction of atheroSclerotic coronary arteries caution 1988;77:43-52.

141 Nabel EG, Selwyn AP, Ganz P. Paradoxical narrowing of atherosclerotic coronary arteries induced by increases in heart rate. Circulation 1990;81:840-59.

142 Drexler $H$, Zeiher AM, Wollschläger $H$, Just $H$. Selective endothelial dysfunction in patients with hypercholesterolemia and angiographically normal coronary arteries [Abstract]. J Am Coll Cardiol 1990;15(suppl A):158A.

143 Lamping KG, Dole WP. Acute hypertension selectivity potentiates constrictor responses of large coronary arteries to serotonin by altering endothelial function in vivo. Circ Res 1987;61:904-13.

144 Van de Voorde J, Leusen I. Endothelium-dependent and independent relaxation of aortic rings from hypertensive rats. Am J Physiol 1986;250:H711-7.

145 Wei EP, Kontos HA Christman CW, DeWitt DS, Povlishock JT. Superoxide generation and reversal of acetylcholine-induced cerebral arteriolar dilation after acute hypertension. Circ Res 1985;57:781-7.

146 Panza JA, Quyyumi AA, Brush JE Jr, Epstein SE. Abnormal endothelium-dependent vascular relaxation in patients with essential hypertension. $N \mathrm{Engl} \mathrm{J} \mathrm{Med}$ 1990;323:22-7.

147 Gebremedhin D, Koltai MZ, Pogatsa G, Magyar K, Hadhazy P. Influence of experimental diabetes on the mechanical responses of canine arteries: role of endothelium. Cardiovasc Res 1988;22:537-44.

148 Harris KH, MacLeod KM. Influence of the endothelium on contractile responses of arteries from diabetic rats. Eur $J$ Pharmacol 1988;153:55-64.

149 Kamata K, Miyata N, Kasuya Y. Impairment of endothelium-dependent relaxation and changes in levels of cyclic GMP in aorta from streptozotocin-induced diabetic rats. Br J Pharmacol 1989;97:614-8.

150 Saenz de Tejada I, Goldstein I, Azadzoi K, Krane RJ, Cohen RA. Impaired neurogenic and endotheliummediated relaxation of penile smooth muscle from diabetic men with impotence. $N$ Engl J Med 1989; 320:1025-30.

151 Factor SM, Sonnenblick EH. The pathogenesis of clinical and experimental congestive cardiomyopathies: recent concepts. Prog Cardiovasc Dis 1985;27:395-420.

152 Hutchison SJ, Poole-Wilson PA, Henderson AH. Angina with normal coronary arteries: a review. $Q \mathrm{~J}$ Med 
1989;72:677-88.

153 Cannon RO III, Watson RM, Rosing DR, Epstein SE Angina caused by reduced vasodilator reserve of the small coronary arteries. J Am Coll Cardiol 1983;1:1359-73.

154 Griffith TM, Hughes Edwards D, Lewis MJ, Henderson AH. Ergometrine-induced arterial dilatation: an endothelium-mediated effect. J Moll Cell Cardiol 1984;16: thelium- 82 .

155 Henderson AH. Syndrome X. Cardiovasc Drugs Ther 1989;3:271-4.

156 Kaiser L, Spickard RC, Olivier NB. Heart failure depresses endothelium-dependent responses in canine femoral artery. Am J Physiol 1989;256:H962-7.

157 Treasure CB, Vita JA, Cox DA, et al. Endotheliumdependent dilation of the coronary microvasculature is impaired in dilated cardiomyopathy. Circulation 1990; 81:772-9.

158 Miller VM, Aarhus LL, Vanhoutte PM. Modulation of endothelium-dependent responses by chronic alterations of blood flow. Am J Physiol 1986;251:H520-7.

159 Andrews HE, Bruckdorfer KR, Dunn RC. Low-density lipoproteins inhibit endothelium-dependent relaxation in rabbit aorta. Nature 1987;327:237-9.

160 Tomita T, Ezaki M, Miwa M, Nakamura K, Inoue Y. Rapid and reversible inhibition by low density lipoprotein of the endothelium-dependent relaxation to lipoprotein of the endothelium-dependent relaxation to hemostatic substan

161 Galle J, Bassenge E, Busse R. Oxidized low density lipoproteins potentiate vasoconstrictions to various agonists by direct interaction with vascular smooth muscle. Circ Res 1990;66:1287-93.

162 Kugiyama K, Kerns SA, Morisett JD, Roberts R, Henry PD. Impairment of endothelium-dependent arterial relaxation by lysolecithin in modified low-density lipoproteins. Nature 1990;344:160-2.

163 Steinberg D, Parthasarathy S, Carew TE, Khoo JC, Witztum JL. Beyond cholesterol. Modifications of lowdensity lipoprotein that increase its atherogenicity. $N$ Engl J Med 1989;320:915-24.
164 Asakura T, Karino T. Flow patterns and spatial distribuCirc Res 1990;66:1045-66.

165 Caro CG, Lever MJ. The mass transport of the arterial wall: effect of mechanical stresses and vasoactive agents, wall: effect of mechanical stresses and vasoactive agents,

166 Curmi PA, Juan L, Tedgui A. Effect of transmural pressure on low density lipoprotein and albumin transport and on low density lipoprotein and albumin transport and distribution across

167 Fry DL. Mass transport, atherogenesis and risk. Arteriosclerosis 1987;7:88-100.

168 Booth RFG, Martin JF, Honey AC, Hassall DG, Beesley JE, Moncada S. Rapid development of atherosclerotic lesions in the rabbit carotid artery induced by perivascular manipulation. Atherosclerosis 1989;76:257-68.

169 Ross R. The pathogenesis of atherosclerosis-an update. $N$ Engl J Med 1986;314:488-500.

170 Reidy MA, Silver M. Endothelial regeneration. VII. Lack of intimal proliferation after defined injury to rat aorta. Am J Pathol 1985;118:173-7.

171 Moore S, Friedman RJ, Singal DP, Gauldie J, Blajchman MA, Roberts RS. Inhibition of injury induced MA, Roberts RS. Inhibition of injury induced thromboatherosclerotic lesions by anti-plat

172 Garg UC, Hassid A. Nitric-oxide generating vasodilators and 8-bromo cyclic guanosine monophosphate inhibit mitogenesis and proliferation of cultured rat vascular smooth muscle cells. J Clin Invest 1989;83:1774-7.

173 Abell TJ, Richards AM, Ikram H, Espinier EA, Yandle T Atrial natriuretic factor inhibits proliferation of vascula smooth muscle cells stimulated by platelet-derived growth factor. Biochem Biophys Res Commun 1989, 60:1392-6.

174 Barrett ML, Willis AL, Vane JR. Inhibition of plateletderived mitogen release by nitric oxide (EDRF). Agents Actions 1989;27:488-91.

175 Assender JW, Southgate KM, Newby AC. Does nitric oxide inhibit smooth muscle proliferation? J Cardiovasc Pharmacol 1991 (in press). 


\section{BRITISH CARDIAC SOCIETY NEWSLETTER}

We have news from the European Society of Cardiology that will by now be known to most of our members. After the untimely death in January of Attilio Reale, Michel Bertrand (who was President Elect) has been appointed Acting President until his own term of office is due to begin in 1994. Professor Bertrand is well known in Britain as in the rest of Europe. We wish him well. We are also delighted to report that in 1995 the European Society of Cardiology will almost certainly be coming to Birmingham, so that the British Cardiac Society will have the privilege of being hosts to a major European meeting for the first time.

Readers may remember that the joint British Cardiac Society/Royal College of Physicians Audit Committee has at present three major projects. The visits between district general hospitals, the national confidential enquiry into cardiac catheter complications (CECCC), and the survey of delays to treatment in acute myocardial infarction are all going well and their scope is being widened as had previously been planned. Nick Brooks who is chairman of the committee is now requesting that members of the society should let him know of other initiatives that are felt to be important. Some suggestions have been made, but before new priorities are decided we are anxious to consider as many appropriate ideas as possible. Please write either direct to Nick Brooks or to us at the society.

David de Bono has written about the confidential enquiry on catheter complications. Cardiac catheterisation and coronary angiography are fundamental to modern cardiology: good equipment and skilled operators have made them safe procedures, but complications do sometimes occur. In August 1990 the Joint Audit Committee of the British Cardiac Society and the Royal College of Physicians of London set up a pilot study of five cardiac centres with the aim of pooling information about catheter laboratory complications, so that the lessons learned could be shared and common factors, in particular complications, would be recognised. This initiative was reported briefly in the newsletter of December 1990. The pilot study has been very successful and it is now intended to extend the scheme to all United Kingdom catheter laboratories. The scheme is being coordinated from the Department of Cardiology in the University of Leicester, and individual units will have been approached by the time this newsletter appears. The data required from each centre are very modest, and a monthly newsletter from Leicester will keep participants informed of progress. David de Bono is anxious to stress that all information will be treated as strictly confidential. We hope that every centre will respond with enthusiasm.

We also wish to draw attention to another important survey coming from Leicester, this one organised by Peter Hubner. Since 1988 the British Cardiovascular Intervention
Society has undertaken a survey of all adult and paediatric intervention procedures (angiography and balloon dilatations). The report on the second survey from 1989 is soon to be published, and the third enquiry was sent out for completion by the end of January. By the time of writing (mid-March), 21 adult National Health Service units, two private units, and 10 paediatric units had replied. A total of 34 units had not. In these days of audit, information technology, and competitive costings, this type of information should be readily available to support a department's activities and budgets. The replies from all units are needed before the 1990 audit can be analysed. By now perhaps the response will be complete. If not, we hear a threat to publish a list of non-responders. .

Peter Hubner has agreed to extend the scope of his survey on behalf of the British Cardiac Society, though the additional scheme will be serviced for us by the British Cardiovascular Intervention Society. We wish to give every trainee cardiologist the opportunity to register all procedures he or she undertakes-angiography, pacemaker implants, electrophysiology studies, as well as intervention procedures. The British Pacing and Electrophysiology Group have indicated their approval. This will be a voluntary scheme, but registration on a monthly basis will aid accurate counting, and will lend credence to claims relating to practical experience-particularly in connection with applications for posts. Will this be supported? Our surgical colleagues have long had a similar scheme and find it helpful.

We have news on the composition of the Cardiac Technicians Committee which is being set up under the chairmanship of Duncan Dymond. The committee will consist of one nominated council member from each of the five affiliated working groups. So far individuals have been nominated from three of the groups; those from echocardiography and pacing and electrophysiology are awaited. The vice chairman of the Society of Cardiological Technicians will also be on the committee as will the President of the British Cardiac Society. Duncan Dymond will represent the British Cardiovascular Intervention Society, Shakeel Qureshi will represent the Paediatric Cardiology Group, and Jane Flint will represent the Nuclear Cardiology Group. Although the final composition of the committee has not been formulated, the principal aims of the committee will be to seek ways of improving the training and of raising the entry standards of cardiological technicians in the United Kingdom (which should result in further improvements in their status), and to forge closer links with the Society of Cardiological Technicians. These have not been as strong as many would wish, and much of the responsibility for this must rest with the cardiologists.

We will end on a lighter note. Do al consultant cardiologists in district hospitals now have a fax machine within their homes? Students of Latin will feel this question should begin with the word "num" (and those not well versed in the classics can contact us in confidence for an explanation). The advantages are considerable. We have all agonised on whether a telephone description of an electrocardiogram represents ventricular tachycardia or something more benign, and perhaps more recently we have hoped for inspiration when the telephone evidence seems inadequate on whether or not thrombolysis is indicated. Should we go in to the hospital at 4 am knowing that it will not then be worth returning home for breakfast? Is it not better to have an electrocardiogram waiting by the telephone when we wake up? The cost of a fax machine is now less than that of a single ampoule of one of the thrombolytic agents. Is it not worth it for the sake of better patient care and more confident and better rested consultants?

DOUGLAS CHAMBERLAIN President, British Cardiac Societ PAUL OLDERSHAW Secretary, British Cardiac Society, 1 St Andrew's Place, London NWI $4 L B$

NOTICES

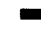 (20) \\ A course on the use of New Devices for the Cardiac and Peripheral Vascular Laboratories will be held in Orlando, Florida, on 1 to 3 July: Shadyside Hospital, New Devices Technology Workshop, 5230 Centre Avenue, Pittsburgh, PA 15232, USA (412 623-1051).}

Angioplasty 1991: A Live Demonstration Course presented by the San Francisco Heart Institute will be held in San Francisco on 12 to 15 August: Steve Lugon, Course Coordinator, San Francisco Heart Institute at Seton Medical Center, 1900 Sullivan Avenue, Daly City, CA 94015, USA (Fax: 415-755-7315; Tel: 415-991-6355).

\section{2}

The Annual Meeting of the British Cardiac Society will take place at the Harrogate International Centre on 26 to 29 May.

1993

The XVII World Congress on Diseases of the Chest sponsored by the International Academy of Chest Physicians and Surgeons will be held in Amsterdam on 13 to 18 June: ACCP, Division of Education, 3300 Dundee Road, Northbrook, IL 60062-2348, USA (Fax 708-498-5460; Tel: 708-498-1400).

\section{CORRECTION}

St Cyres lecture. Endothelium in control $A H$ Henderson (March issue, volume 65: pages 116-25) - The author has asked us to point out that reference 142 should have read: Zeiher AM, Drexler H, Wollschläger H, Just $H$. Modulation of coronary vasomotor tone in humans. Circulation 1991;83:391-401. 